University of Rhode Island

DigitalCommons@URI

Open Access Master's Theses

1985

\title{
A Critical Examination of Four Selected Attempts to Establish Objective Ethical Norms Without Recourse to a Transcendent Source
}

Paul A. Sauer

University of Rhode Island

Follow this and additional works at: https://digitalcommons.uri.edu/theses

\section{Recommended Citation}

Sauer, Paul A., "A Critical Examination of Four Selected Attempts to Establish Objective Ethical Norms Without Recourse to a Transcendent Source" (1985). Open Access Master's Theses. Paper 1663. https://digitalcommons.uri.edu/theses/1663

This Thesis is brought to you for free and open access by DigitalCommons@URI. It has been accepted for inclusion in Open Access Master's Theses by an authorized administrator of DigitalCommons@URI. For more information, please contact digitalcommons-group@uri.edu. 
A CRITICAL EXAMINATION OF FOUR SELECTED

ATTEMPTS TO ESTABLISH OBJECTIVE

ETHICAI NORMS WITHOUT RECOURSE

TO A TRANSCENDENT SOURCE

$B Y$

PAUL A. SAUER

2. THFSIS SUBMITTED IN PARTIAL FULFILLMENT OF THE REQUTREMENTS FOR THE DEGREE OF

MASTER OF ARTS

IN

PHILOSOPHY

UNIVERSITY OF RHODE ISLAND

1985 


\section{ABSTRACT}

In this thesis four secular approaches to ethics which purport to either establish or lay the theoretical foundation for establishing objective ethical norms come in fo: a critical examination: These are: 1) the naturalism of Richard Taylor, 2) the linguistic corventionalism of John R. Searle, 3) the existentialist chcice of Jear-Paul Sartre, and 4) the openly "ontological" strategy of Herry Veatch. Each of the above theories seeks to establish, explicitly or implicitly, a normative ethical reguirement to respect the rights, freedom, ete. of other human beings. Using a consistent individualistic egoism as a foil, it is argued that each of the four theories considered fails, on the basis of its own initial assumptions concerning "goodness," "rightness," "obligation," the ontological status of man, etc., to turn back the challenge posed by the egoist. Ezch of the four theories is viewed as an unsuccessful attempt to derive a normative ethical "ought" from a factual, descriptive "is." In the final section of the thesis the four secular ethical theories are contrasted with a theistically based theory of ethics, and it is argued that the latter has a distinct advantage over the former with regard to the establishment of objective ethical norms. Finally, epistemological probiems associated with the establishment of the foundational assumptions of all the theories are briefly cominerted on. 


\section{ACKNOWLEDGEMENT}

I gratefully acknowledge the assistance rendered to me in the preparation of this manuscript by the members of my thesis committee: Professors Fritz Wenisch and William Young of the Philosophy Department, and Professor Richard Bailey of the Speech-Communications Department of U. R. I. The above individuals, through a careful and critical examination of the drast manuscript, brought to my attention both dubious assertions and gaps in my argumentation. Needless to say the remaining errors and questionable points are to be attributed entirely to the author. I owe a special debt of gratitude to my advisor and major professor, Fritz wenisch, for investing a great deal of time and effort into the examination and improvement of the thesis. He is to be particularly commended for his patience with my persistent and sometimes contumacious argumentation over excellent points which he raised. 
TABLE OF CONTENTS

PAGE

I. Abstract. . . . . . . . . . . . . ii

II. Acknowledgement . . . . . . . . . . . . iii

III. Table of Contents.... . . . . . . . iv

IV. Introduction . . . . . . . . . . . . . I

V. Niethodology . . . . . . . . . . . . 8

VI. Egalitarian Naturalism: Richard Taylor... 13

VII. Searle: Linguistic Conventionalism. . . . 30

VIII. Sartre: Good Faith. . . . . . . . . . 45

IX. Veatch: An Ontology of Morals........ 51

x. Concluaing Epistemological Postscript. . . . 67

XI. Footnotes................ 80

XII. Bibliography. . . . . . . . . . . 84 


\section{INTRODUCTION}

Dostoevsky declared that if God didn't exist everything would be possible, and Sartre called this declaration "the very starting point of existentialism." 1 At the other end of the philosophical spectrum post-world War II analytic philosophers have largely reduced ethics to meta-ethics-analysis of the language of morals with little or no concern for what Henry Veatch calls an ontology of morals. That both of these approaches deprive ethics of any foundation ante rem and lead to an unbridled relativism shall be argued here. Indeed, I- shall argue for the wider thesis that the existence of objective ethical norms requires the existence of a transcendent source of such norms, and here I an referring to something akin to the classical JudaeoChristian concept of God. At this point, however, I merely wish to point out the fact that there exists a certain uneasiness in contemporary society concerning the status of ethical injunctions. A pervasive relativsm has led to freedom from "old fashioned" conventional morality, but nothing firm has been put in its place.

A general malaise grips us, an ill-defined feeling that something is not right in the realm of etrical values. As a result there has been, in the last fifteen years or so, a recrudescence of interest in moral values that are somehow "out there" independently 
of our desires and whims, and a correlative dissatsifaction with ethical systems and meta-ethical approcches which fail to provide or even acknowledge the possibility of such values. This dissatisfaction exists not only on the level c.f the "common man," but also on that of the professional philosopher of ethics. The naturalist, Richard Taylor, deprecates "the baggage of what has pretentiously come to be known as "metaethics," 2 finding discussions of what is meant by this or that ethical term "poor substitutes for what a wise man ought to think about things of human significance."3 Henry veatch, who approaches ethics from ar ontoiogical standpoint aiametrically opposed to that af Taylor, nonetheless applauas his comments about meta-ethics. Veatch would soive the probiems of meta-ethics by proviaing an ontological basis tirough what he describes as meta-meta-ethics. Mary warnock views metamethics as trivializing the subject of ethics. Speaking of Englisi analytic moral philosophers, she maintains that "they are inclinea to believe that, in $t$ eory at ieast, abs olutely arything could count as a moral c inior, or a no:al princiole, provided it was framed in $t$ e ray lid cown or $s$. ch? inciples, and used, as the ase $\therefore$ ed, to cuide coiduc: " " juch relativism stering from ne aethics and, to an even gr. zte extent accorcing to warnock, from Marxist socioloyy, cunst..tuts s the "rutst nding problem in ethics at the present time." 5 In citing the above authors it is not my intent to disparage meta-ethics in genera:, but rather to call attentio:. to what is perceived by them to be 
a neglect of the "meat " of actual ethics and/or a relativism characteristic of the meta-ethical approach, without implying that these faults are inherent in meta-ethics.

I have said that I shall argue that objective ethical norms are impossible without a transcendent author. It will be helpful at this juncture to give some idea of what is meant by "objective," although this is no place for a full fledged discussion of the relevant epistemological and metaphysical questions. First, by way of contrast, I do not mean by "objective," conventional, either social or linguistic. I do mean by "objective," ethical norms that are not dependent upon being perceived and acknowledged by a human subject, but rather are "out there" independently of being recognized by this or that individual or community. Since I do not take a naturalist position (in the sense of holding that normative ethical statements are verifiable by empirical observation) this commits me to a belief in the reality of non-empirical entities, to some form of metaphysical realism. This not being a thesis on metaphysics per se, I shall merely state and not defend my realist presupposition here. However, there is an objection that needs to be addressed, if only briefly, at this point. By defining "objective" as I do, am I setting up the terms of the problem in such a way that my thesis must necessarily follow? Am I guilty of a petitio principii? I do not believe that this is the case; however, my argument against such a charge will be deferred. 
objective ethical norms may be viewed as absolute, inviolable, and "rationally unquestionable" principles. In his analysis of ethical positions James Fishkin defines the above position as "absolutism.". He presents two other positions which he considers objectivist. The second is identical to the first except for the withdrawal of the claim that moral judgments are rationally unquestionable. The third, which he calls "minimal objectivism" drops the inviolability criterion, allowing that ethical judgments may be formulated as prima facie propositions. In addition, Fishkin makes reference to what he calls "the appropriate moral perspective." The third form of objectivism is such that: "One's judgments are objectively valid; that is, their constant application to everyone is supported by considerations that anyone should accept, were he to view the problem from what is contended to be the appropriate moral perspective." 6 This perspective is seen as some sort of impartial viewpoint, either expressed informally (e.g., the Golden Rule), or formally in a moral decision procedure. The first two of Fishkin's positions would qualify for the title "objective" as I am using the term, and, assining that there is a single "appropriate moral perspective" so would the third. Obviously I am allowing considerable latitude in my operative notion of "objective." No attempt will be made here, for example, to determine whether or not normative ethical judgments must be inviolable or merely prima facie. I do not believe that it is 
necessary to provide definitive answers to questions such as this in order to address the wider question of whether objective moral judgments are possible in the absence of a transcendent author. However, the question as to whether or not there is an "appropriate moral perspective" will occupy us Eurther.

In connection with Fishkin's notion of "absolutism" we have seen a reference to "rationally unquestionale" principlis. It will be useful to say a few words about the concept of rationality, or "reasonableness" employed by Fishkin alori with many other writers on ethics. Two rather different notions of "rational" (or "reasonable") are to be encountered ir ciscussions of morality. The first is the strict, narrow concept of being consistent with the laws of formal logic (e.g., non-contradiction, excluded middle, etc.). The second, and by far the more common, is a broader concept that is much harder to define, and which is often used in a slyly tendentious manner. I might try to capture a general idea of this broader use with such phrases as "what any reasonable man would accept," or "concerning which doubt and skepticism is inappropriate." It is rather obvious that an author can attach this sort of idea to his pet moral principles in order to avoid having to defend them by actually giving reasons for them. The terms "rational" and "reasonable" have a strong positive connotation, and once an author can "baptize" his fundamental ethical principles with these 
terms he is on the way to having them accepted. Particularly where such appellations are never explained and are casually accepted by the reader, he may consciously or unconsciously come to attach the first, logically rigorous, meaning of these terms to the author's precepts. Fishkin is not guilty of attempting to pull off this sort of sleight of hand, openly acknowledging that he is using "rationally unquestionable" in a wide, not precisely defined sense: "Perhaps it is a necessary truth, if such a thing is possible in ethical matters. Or if it is not a necessary truth, it has a kind of apodeictic basis that renders further skepticism inappropriate." 7 Kant's "categorical imperatives" provide an illustration for Fistikin of ethical injunctions on behalf of which such a claim of being "rationally unquestionable" has been made. Certainiy Kant would not claim that someone who denied any categorical imperative necessarily committed a formal logical fallacy in doing so.

other writers do not echo Fishkin's restraint, but rather make free use of the label "rational" to propagandize their own ethical positions. Thus Paul Kurtz writes that ". . human beings can take a rational approach to a moral life, which would include a moderation of appetites and a compassionate concern for the needs of others. . The aim of a rational morality is to maximize individual freedom, selfrealization, and human happiness throughout society." 8 How or why moderation (rather than unrestrained indulgence) of 
appetites, compassionate concern (rather than total indifference) for the needs of others, individual freedom (rather than totalitarian suppression) etc. are more rational than their opposites Kurtz doesn't explain. A similarly tendentious use of ? ztionality is seen in Farber's comment that "The achievement of a predatory entrepreneur--that is, the use of other men merely to advance one's own interests--cannot be accepted at face value in any rational ethics." 9 Surely there is no implication here that the ethical guidelines employed by a predatory entrepreneur necessarily violate the canons of formal logic. The concept of a "rational morality" employed by kurtz and other modern humanistic authors has a long and honourable pedigree, going back to Plato and Socrates. However, these early rationalists based ethics on an ontological foundation which has long been abanacned by Kurtz and other modern writers of the empirical, humanist tradition. For Plato something was good if it participated in the Form, Goodness. Such participation was to be ascertained by focusing the "eye of the mind" upon the world of the forms, a process that was greatly facilitated by ignoring the desires of the body. That the forms are real (indeed that they are the only things that are fully so) is a tenet of Platonism. For something to be rational or reasonable means that it is apprehended by the mind as it focuses upon the forms. Thus the ertire notion of rationality, a wide notion that goes well beyond the canons of formal logic, is intimately and intricately connected to an 
ontology of eternal, unchanging forms for classical Platonic rationalism. Most Platonists would agree with Kurtz that such things as concern for others, individual freedom, etc. are rational in the classical sense. They, however, have an ontology upon which to base such a claim whereas Kurtz and others like him do not. In the case of the latter claims that compassionate concern, freedom, etc. are "rational" are left hanging in the air. They are using the borrowed capital of classical rationalism which they have, in theory, long since abandoned. Thus without an undergirding ontology those who would use "reason" or "rationality" in ethics are limited to critiquing ethical systems from the standpoint of internal coherence. They may not legitimately use "reason" as a tool for establishing a priori this or that ethical proposition.

\section{METHCDOLOGY}

An apodictic proof of the sort of universal negative thesis which I am advancing is impossidie. I am examining the thesis that there cannot be objective ethical norms without a transcendent (personal) source of those norms. If true, this thesis entails that every attempt to demonstrate the existence of such norms independent of a transcendent source must necessarily fail. Even if it were feasible (which it here is not) to consider every historical attempt to found objective ethical norms on a non-transcendent basis, 
it would not be possible to anticipate all future attempts to complete this project. Therefore, for practical reasons I shall proceed by selecting for critical examination certain representative secular ethical theories which attempt to put ethics on an objective basis. For each theory selected I shall show that it fails by being unable, on the basis of its own initial assumptions and without an explicit or implicit ad hoc "egalitarian" maneuver, to refute the objections of a consistent individualistic egoism. That is, in each of the secular theories considered an attempt is made to derive a principle whereby the rights (or at least a certain particular right--e.g., to have promises kept) of others must be respected equally with one's own. I argue that such a prinsiple neither follows logically from nor is even congruous with the initial metaphysical and other axiomatic assumptions of these theories. Thus in orcer to derive the "egalitarian" principle, an ad hoc assumption must be added along the way. I hope to show that, in contrast, a theistically based ethical theory requires no such ad hoc move. While an assumption rust indeed be added to the initial metaphysical premises of a theistic ethics in order to obtain a requirement to respect the rights of others, I argue that this assumption is congruous with the initial premises of the theory, and prima facie plausible, whereas in the cases of the secular theories examined such is not the case. Rather, in these latter instances the ad hoc character of the "egalitarian" 
assumption is all too evident. Thus I am claiming a distinct advantage for a theistically based ethics vis-a-vis the four secular theories examined. It does not follow from my claim, if substantiated, that all attempts to derive objective ethical norms on a non-theistic basis must, in principle, fail. Any such attempts which differ significantly from the four approaches which I critically examine would have to be evaluated on the basis of their individual merits. Nevertheless, it remains true that I have come to grips with three of the more prevalent non-theistic 20th century approaches to ethics plus the "throwback" ontological approach of Veatch. If I have successfully shown that these non-theistic approaches are unable to make a cogent case for the existence of objective ethical norms, this finding is of no small significance. The procedure which I follow here leads naturally to questions concerning the selection of first principles or axioms, and to consiceration of the basic epistemological question: "How do we know anything?" Here I will have something to say about the sources of first principles and the circularity of metaphysical arguments in general. These considerations will lead to the question of whether or not my thesis results in epistemological skepticism and a reduction of epistemology to psychology. Finally I shall return to the matter of the ontological basis of ethics, mentioned briefly in the introduction.

I have selected four representative ethical theories for critical appraisal. The first is what I shall label the 
egalitarian naturalism of Richard Taylor. In this type of theory the good is defined in terms of actual human desires and "needs," the sorts of things that behavioral scientists can get a grip on. This type of theory (and Taylor's is an example of this) is almost always accompanied by some sort of egalitarian/altruistic assumption in order to ward off the individualistic egoist when dealing with conflict of desires/needs sitlations. The second theory which shall come under scrutiny is the linguistic conventionalism of John Searle, and his attempt to do ethics without ontology shall be shown to be futile. Next I shall take up the existential choice approach of the early sartre. While it may sound strange to include Sartire in a selection of purportedly objectivistic ethical theories, there are certain key tenets of his existentialist ethics which Sartre regarded as absolute and unchallengeable. It is these which shall be called into question. The last theory about which I shall comment is the openly ontological approach of Henry veatch which, while on the right track for the establishment of objective ethical principles, doesn't go far enough.

By focusing on these four modern theories I am obviously neglecting classical approaches such as utilitarianism and Kantian deontologism. While I shall not address separately these and other historical theories, much of what I have to say will be relevant to them. For instance, the egoistic critique of Taylor can be applied, mutatis mutandis, to utilitarianism. Furthermore, comments (not necessarily 
negative) pertaining to intellectual insight which shall be made in the final section on epistemology will be germane to deontological ethical systems. I shall try to point out the more important of such applications as I go along.

There are many areas which are relevant to this thesis but which will not be addressed except for a few passing comments. Since I am dealing with approaches to ethics which purport to establish objective norms in some meaningful sense of this term, I shal: not discuss openly subjectivist ethical formulations (e.g., Ayer, Westermarck, Benedict) per se. Aiso such a qusstion as whether or not subjectivism is selfrefuting, recently discussed in a very interesting manner by C. Betan McCullagh, is beyond the scope of this thesis. There is one obvious point with respect to relativism which may be mentioned. If my negative thesis is accepted and attached to an assumption of atheism, by logical necessity we are left with some form of relativism as the only remaining ethical position possible (or amoralism if this is regarded as an ethical rather than a meta-ethical position). As Hancock has pointed out, the distinction between ethics and meta-ethics is not at all easy to draw. Indeed Fishkin regards subjectivism itself as an "essentially" meta-ethical phenomenon. It follows from the ajove that I shall not here deal with the ethical ass imptions of Marxist sociology (class determined ethics) which, as Mary Warnock points it, has become a powerful influence upon ethical th or' in rerent years. This is, after all, a form of relativisia, although 
not without a tension produced by certain absolutistic presumptions. Finally, I shall not address the thorny free will vs determinism question other than to state the undefended assumption that human beings may be held morally responsible for their actions.

\section{EGALITARIAN NATURALISM: RICHARD TAYLOR}

I have chosen the label "egalitarian naturalism" to describe Taylor's ethics: 1) to distinguish it from classical utilitarianism, and 2) to emphasize the fact that an egalitarian assumption accompanies his naturalism, in contradistinction from an egoistic naturalism. Where utilitarianism (e. . , Bentham) regarded pleasure as the good, Taylor takes into account the existing diversity of human needs and desires, declaring that good and evil are to be defined in terms of their satisfaction and frustration, respectively. Thus for Taylor there is no aistinction between the "is" and the "ought." Rejecting the classical tradition of Plato, Aristotle, etc. whereby reason was given the primacy over will in ethics, Taylor unabashedly reverses their roles. There is no "natural morality" for Taylor in the sense of a morality somehow discoverable by reason and which is superior to a "conventional morality." In this respect Taylor finds no significant difference between Plato and Kant's "natural 
law," categorically rejecting both. Sharply circumscribing the role of reason in ethics, Taylor declares that, in accordance with moral voluntarism (his view): ". . it is only because a man has a will--that is, because he has desires, passions, wants, inclinations, or in short, because he pursues ends or objects of desire--that any distinctions of good and evil ever arise in the first place. The original goodness of something consists simply in its being desired, and the evil of any state of affairs consists simply in its frustration of desire. . . the question cannot even legitimately arise of whether what a man wills corresponds with what is rationally good. Reason, by itself, can make no distinction whatever between what is good and what is not." 10 The will is that which detects good and evil in anything for Taylor, since it is the will which detects actual desires. The role of reason is essentially to discover the optimal means to attain desired ends. Goodness "is simply the satisfaction of needs and desires, or what can generally be described as the fulfillment of purposes. The greatest good for any individual can accordingly be nothing but the total satisfaction of his needs, whatever these may be."ll while this is his theoretical position, Taylor does not hold that such a total satisfaction is practically possible. Nonetheless, Taylor is rigorously consistent in defining good and evil in terms of actual desires and needs, holding that in and of themselves desires are without moral significance. Thus "...desires or 
purposes themselves can be neither good nor bad. The mere fact that a desire exists, that something is wanted, or that something is regarded as a goal, entails that the desire should be fulfilled or the goal achieved; that is to say, that such satisfaction would be a good for him who wants it. It matters not in the least what the desire is."12 Elsewhere Taylor makes his basic point in the following terms: "...things are, originally, good precisely because they are sought, and evil because they are shunned. The seeking and shunning is what gives rise to the distinction between good and evil. It is, therefore, an empty injunction to say that men ought to pursue good and avoid evil, as this amounts only to saying they should seek what they seek and avoid what they avoid."13 For Taylor it is not an open question whether or not the things men seek are good.

The notions of right and wrong are derivative in Taylor's ethics, being, like those of good and evil relative to the actual desires and needs of men. Put simply, any action which furthers the satisfaction of actual needs or desires is right; conversely, an action which frustrates such satisfaction is wrong. All of this is to be seen against the backdrop of Taylor's view of human nature. As human beings we "are basically egoistic or selfish and look first and last to the satisfaction of our own wills and desires..."14 Furthermore, Taylor acknowledges that a morality may be built upon the egoistic satisfaction of their desires by the 
naturally superior (in terms of actual ability--physical, intellectual, etc.) at the expense of the inferior. This is the morality of Callicles in Plato's Gorgias which "was evidently not refuted by Socrates, and has probably never been refuted by anyone else--although it has been rejected by virtually every moralist who has considered it." 15 As we shall see Taylor's purportedly objective system of morality proves to be no match for a consistent egoism either. While to my knowledge Taylor nowhere specifically labels his morality as a species of "objectivism," I believe that tris is a fair characterization even though he occasionally uses language which has a subjectivistic ring (e.g. things are good "precisely because they are sought." Presumably Taylor would agree with Rollo Handy that the question of what actually are human needs and desires is to be answered by behavioral scientists through studying the facts of human behavior. These facts would be objectively established, and, for Taylor, coupled with the a priori assumption that the satisfaction of these needs and desires is good. Even if this line of approach were to be acknowledged as valid, however, it would not be such a straightforward endeavor. The presuppositions and assumptions employed by behavioral scientists in the collection and interpretation of their data would have to come under scrutiny as well as the data itself. However, I shall not develop this point; my assault on Taylor shall come from another quarter. 
Since I intend to utilize consistent egoism as a weapon against Taylor (as well as the other moral positions to be critically examined), it would be advisable to deal with an objection which is designed to invalidate my line of attack before it can get started. This is the charge that egoism is a form of amoralism and therefore cannot be legitimately used as a foil against various moral positions. Taylor himself takes this line, declaring that "seif-seeking, insofar as it is just that, is morally neutral ir both animals and men." 16 He notes that "It is simply a fact that men do normally so act. To regard any man as blameworthy or praiseworthy for this is as pointless as it would be to praise or blane nim for having a mother." 17 That Taylor is in no position to thus disqualify egoism as a moral position can be seen from an examination of the fourdation for his own position. It is, he acknowledges, simply a fact that men do have certain felt needs and desires, yet it is upon this fact that Taylor builds his fundamental notions of good and evil. If he is entitled to proceed in this manner, then he cannot reasonably object to the egoist who, more narrowly, operates fron the perspective of the individual's needs and desires. This is sufficient mention of this point for the moment; the difference between Taylor and rational egoism will become cleserer when we examine the egalitarian assumption of the former.

It is, of course, stili possible to attack egoism as a moral position without relying upon Taylor. The general 
argument would be that individualistic egoism lacks the proper "moral point of view," "moral perspective," etc., the implication being that morality is by its very nature othercentered. This maneuver is obviously question begging with respect to egoism, crudely attempting to rule it out of bounds by definitional fiat. If the egoist claims that his position is a moral one (e.g., as Callicles claimed that the naturally stronger ought to rule over the weaker in the interest of the advantage of the former), the altruist cannot legitimately rule the egoist out of bounds for the purpose of moral discourse by means of an arbitrary definition which excludes the egoist's position.

We have looked at Taylor's basic notions of good and evil, right and wrong. It is now time to see how they function in situations involving human int action and conflict, in short to ascertain what sort of ethics Taylor can derive from them. Even if human needs and desires were the same for all people, the human condition is such that it would not be possible for each individual to satisfy each of his felt needs and desires. Part of the reason for this situation is that others compete with him for limited satisfiers. Thus conflict is inevitable as various individuals attempt to satisfy their needs and desires. Of course, as Taylor correctly notes, there are significant differences from one individual to another in felt needs and desires. Consequently, the situation is more complicated than if everybody had the same needs and desires. In any event 
competition and conflict between individuals necessarily occur. How does Taylor deal with it?

To answer the above question we must examine his notion of the "common good." Before coming to that point, however, it may be useful to say a few words about what Taylor calls the basic priaciple of all rules of conduct in human society: "the minimization of conflict and its consequent evil, and the maximization of cooperation and its consequent good."18 Good and evil are, of course, understood in Taylor's terms. He points out, reasonably enough, the empirically verifiable benefits (goods) frequently derived from cooperative efforts among individuals, and the losses (evils) resulting from violent conflicts. However, it is not true that, in the case of mutual aggression, the possibility of evil to each aggressor "is almost certain to outweigh any possibility of good."19 There are frequent instances of violent conflict between individuals and between nations where the probability of victory is so high for one party that, viewed from that party's standpoint, a "good" outcome of the conflict is far more likely than an "evil" outcome. Even if Taylor were to concede this point, however, this would rot be especially damaging to his case if we were to grant the desirability of striving for what he calls the common good.

While Taylor's formula for the common good has a distinctly utilitarian ring to it, he wishes to distinguish it from classical utilitarianism (e.g., Mill) in two ways. 
First, he replaces the rather simplistic and somewhat vague notions of happiness and pleasure with the satisfaction of specific felt human needs and desires. Second, he wants to avoid a formulation which would theoretically allow for a situation in which a maximum aggregate satisfaction was achieved through the frustration of a significant number of desires. Thus Taylor advances the following general formula for the idea of the common good: "The maximum fulfillment of all those aims that different men actually have, and the maximum satisfaction of their felt desires, whatever these may be, at the least cost--that is, with the minimum frustration of precisely the same aims and desires."20 In fairness to Taylor, he does not pretend that this formula provides us with a precise eans of calculating how to achieve the common good; however, he does claim that it enables us to make "some sort of beginning in appraising various institutions and states of affairs with respect to whether they do, or do not, promote the common good." 21 Taylor believes that by evaluating the tendencies toward advancing or retarding the achievement of the common good that the satisfaction of actual aims and desires have, we can empirically determine which of these are and which are not "morally acceptable or worthy." He thus seeks to avoid having to rely on some sort of "esoteric moral intuition or Platonic insight" in making moral evaluations of human aims and desires. We should keep in mind here that for Taylor human desires are 
inherently amoral; we are entitled to talk about morally evaluating them only insofar as their respective satisfactions make an impact on the achievement of the common good. Taylor's reference to the "minimum frustration" of human aims and desires implies that some degree of frustration is to be regarded as acceptable. This must be the case in view of the obvious fact that some desires can be satisfied only at the expense of the frustration of others. When such conflicts occur, Taylor holds that the "more pressing" (stronger, more important) desire should be satisfied at the expense of the less pressing, important, etc. desire. Where a single individual only is concerned this notion may be acceptable; however, the important conflicts for Taylor's theory are those involving more than one person. In order to settle these he needs a method of ordering aims and desires where different individuals are involvea. At this point it may prove useful to look at a concrete example which Taylor uses to illustrate the application of his theory. This is the institution of slavery. Taylor concedes to the advocates of negro slavery that the number of people whose aims and desires were in some way furthered by this institution outnumbered those whose aims and desires were frustrated. On the debit side of the ledger, however, he finds that "the very basic and supreme ends of any man: the interest in dwelling in freedom, in self-determination and inner pride," 22 etc. are sacrificed in order to achieve the economic advantages of the larger group. Taylor concludes that the differ- 
ence in importance between the frustrated aims and desires and those satisfied via slavery is great enough to outweigh the quantitative factor (whereby more people benefited from slavery than were injured by it), resulting in the determination that slavery made a net negative contribution to the common good and therefore deserved to be done away with.

While it is likely that most people would agree with Taylor's conclusion concerning slavery, this does not require that they arrive at it by weighing more and less important human aims and desires. Slavery is in fact more likely to be rejected on religious grounds or on the basis of a purported insight into the equality of blacks and whites qua men. We have not yet looked at the method by which Taylor actually weighs conflicting aims and desires against each other. In the case involving only a single individual it is easy enough in most instances for him to prioritize conflizting ains and desires (e.g., to resist a craving for certain foods which are likely to have deleterious consequences for his health). The most important interest is the one which the person juages to mean the most to him, and, as Taylor points out, there is no appeal beyond this assessment. The above example is not, however, intended to imply that there are no individuals who prefer a relatively short life in which they indulge as many sensual appetites as possible to a longer one in which they exercise some restraints. The large majority of mankind would, however, fall into the latter category. 
Taylor would employ what he calls "sympathetic projection" in the case of interpersonal conflicts of aims and desires: "when confronted with conflicting interests in different men or groups, then, one can in a similar [to the case of a conflict involving one individual alonel way determine, with some assurance, which should prevail by imagining that both interests are one's own and asking oneself which means the mo...t."23 In the case of slavery one is to put oneself mentally in the position of a slave and "ask himself whether, in that case, the interest of his that would be sacrificed [freedom] would mean more to him than the interest that would be served the economic advantages accruing to him from slavery]." 24 In other words, the moral agent is to place himself in an imaginary conflict situation where he must sacrifice one of these interests in order to achieve the other, and, on the basis of his choice he is to decide the actual conflict situation between different groups of people. Since he would almost certainly choose freedom over certain economic advantages, slavery is to be proscribed. While making a point of keeping his approach free from "presuppositions drawn from religion and traditional morality," Taylor acknowledges a similarity between his idea of "sympathetic projection" and the Golden Rule of the Gospels.

The rational egoist is interested, either primarily or exclusively in the satisfaction of his own desires and aims. Taylor makes an inconclusive argument for the existence of altruistic motivations of human behavior. In each of the 
purported instances of such behavior that he cites it is always possible to offer a counter explanation based upon psychological egoism. That is, it is possible to view any behavior as aimed at the satisfaction of some desire of the agent, no matter how unselfish it may appear on the surface. I do not propose to enter the debate between altruistic and psychological egoistic explanations of human behavior, as this is primarily a psychological question concerning the realm of the "is" rather than the "ought." (If an absolute psychological egoism turned out to be true, this would have devastating consequences for ethics as presently conceived; this problem, however, is beyond the scope of this paper.) In his discussion of individuals' desires and aims Taylor made no distinction between "is" and "ought." A desire, by virtue of its existence should be satisfied. The satisfactions of all desires are goods. However, we have seen that in his discussion of interpersonal interactions he has given us two "oughts," the common good ard the exercise of sympathetic projection, which he claims should be advanced and practiced, respectively. What claim can these have on a rationally consistent egoist?

Taylor is surely right inpointing out that there are situations in which it is to an individual's advantage to provide aid or assistance of some form to another. Such factors as the likelihood of future reciprocation, the good will and respect of one's neighbors and associates, and 
considerations of self interest often come into play and may provide the prospect of a long term net advantage accruing from an action in behalf of someone else. The conclusion to be drawn from this state of affairs by the rational egoist is that he should perform actions in behalf of others whenever, in his best judgment, the net effect will be to his overall advantage. This is a far cry from adopting Taylor's abstract notion of the common good as an object to be pursued. To put it briefly: Taylor has given no reasons why a consistent egoist should consider the common good or engage in sympathetic projection. Taylor is operating with different initial assumptions than those of the egoist; he has adopted an altruistic point of view which the egoist rejects. The latter considers the satisfaction of his own desires and aims as the ultimate criterion of what is "right" and "wrong," ignoring objections that this is inappropriate as a "moral point of view." Taylor has no way of refuting the egoist here, on the basis of his (Taylor's) basic notions of good anä evil. If all desires and aims, considered in and of themselves, are amoral, there can be no objective basis for regarding, say, the sadist's desire to inflict pain on another person as less important than the victim's desire to avoid such pain. The egoistic sadist has no desire to engage in sympathetic projection, and Taylor has given him no reason to do so. Many other comparable examples could be provided. 
The above conclusions apply, mutatis mutandis, to classical utilitarianism and to modern systems of ethics built around the notion of distributive justice accomplished by means of appropriate decision procedures or moral perspectives (e.g., those of Rawls, Singer, Ackerman, and Dworkin). All require an initial acceptance of some sort of egalitarian principle, and have no force against an egoist who refuses to accept such a principle. One should be wary here of those who attempt to smuggle in such a notion under the rubric of "reason" or "rationality." Even Henry Sidgwick, the avowed intuitionist utilitarian, in his discussion of ultimate good in his classical The Methods of Ethics, acknowledged that he held "it no less reasonable Ithan sacrificing one's own happiness for the greater happiness of others] for an individual to take his own happiness as his ultimate end." 25 An analagous concession is made by Rawls to the egoist who refuses to be bound by the results of his decision procedure. He simply dismisses egoism as "incompatible with what we intuitively regard as the moral point of view." 26 As we have already seen this question begging attempt to discualify egoism from the universe of moral discourse will not wash. By making this move Rawls tacitly admits that he has no way of refuting the egoist other than by definitional fiat.

An attempt actually has been made to argue vigorously for an egalitarian principle by means of which the egoist or amoralist could be logically refuted. I refer to Alan 
Gerwith's attempt in Reason and Morality to establish a principle of universal respect for the freedom and well-being of others. In my comments I basically follow Fishkin's refutation of Gerwith's argument. First, the argument: "Every agent must claim, at least implicitly, that he has rights to freedom and well-being for the sufficierit reasons that he is a prospective purposive agent. From the content of this claim it follows, by the principle of universalizability, trat ail prospective purposive agents have rights to freedom and well-being. If the agent denies this generalization, he contradicts himself. For then he would be in the position of both affirming and denying that being a prospective purposive agent is a sufficient condition of having rights to freedom and well-being." 27

In other words, if o:e makes the claim that he has, on the basis of being a prospective purposive agent, rights to freedom and well-being (however these notions are defined), then he must logically grant such rights to all prospective purposive agents (all or nearly all human beings). The core of Fishkin's attack on the above argument lies in the distinction between an agent affirming that his freedom and we1l-being are desirable goods (or even necessary goods in the instrumental sense of being essential to his effective functioning as a purposive agent) and a claim that he has a "right" to freedom and well-being. These are two different claims, and the second does not logicaily follow from the first. Furthermore it is the second, stronger claim the 
that Gerwith must saddle the egoist (or anarchist) with in order to prove his universalizability thesis. The egoist can readily acknowledge that he aggressively seeks to maintain his own freedom and well-being and that he requires both to effectively function as a purposive agent without claiming that he has any "right" to either. Indeed bringing in the notion of "rights" as Gerwith does involves either a convention to which the egoist would feel no obligation to conform, or an assumption which he would reject, and Gerwith has no means to compel him logically to a contrary stance in either case. Rights imply a grantor. Such a grantor must be either a human society or some segment thereof (including an individual) or a power transcending humanity. In the first case the rights are presumably conventional, and the egoist as we have seen has no reason to obey conventions unless this advances his own interests. As for the second alternative, the egoist would reject the assumption of such a power since it would invalidate his basic position by requiring him to consider the desires and needs of others, in at least some instances, ahead of his own. Fishkin points out the following with respect to subjectivist reasoners (and egoists may be so regarded in as much as they claim egoism as a personal ethical choice and not a position that can be objectively established; as long as he can show that purportedly objective contrary ethical positions are unable to refute him, the egoist is satisfied): "Just as they have a 
positive attitude toward their own freedom and well-being, they may grant that others have a similar attitude toward their own (respective) freedom and well-being--without any entitlements or moral requirements following for either party." 28

In the latter portion of his major ethical work, Good and Evil, Taylor makes extensive reference to "the virtue of compassion" as a motive for human actions. Here he presents examples of behavior calculated to cause reactions of revulsion and admiration, respectively, on the part of the reader, and wares eloquently about "noble and beautiful" deeds, and "the compassionate reart" which "makes men akin to the angels and the powers of light, and snuffs out in them the real and ever present forces of darkness and evil."29 All of this stands out in strange contrast to the first two-thirds of the book where he argues, quite unemotionally, for a logical, objective naturalism. In the latter part of the book a turn toward some sort of intuitionism, emphastically rejected earlier, seems evident: "Most men, however, seem to know just what human goodness is when they see it, whether they have read treatises on morality or not, or whether or not they have tried to fathom its metaphysical foundations." 30 Taylor appears to retreat from the earlier confident exposition of his naturalism into an intuitive appeal to a comon moral consciousness of man, perhaps implicitly recognizing the weakness, particularly vis-a-vis egoism, of the 
former approach. Thus when he asks, late in the book, why a rational person should abandon his own self-centered interest in favor of the common good the timid reply is: "I believe no real answer to this question exists." 31

\section{SEARLE: LINGUISTIC CONVENTIONALISM}

The separation between fact (what is the case--discoverable by empirical means) and value which has characterized the analytic tradition in etrics began with G. E. Moore's assertion that goodness was a "non-natural" property which could be somehow intuited but not discovered by ordinary empirical means. The emotivists brought the separation to its logical extreme, denying that goodness was any sort of property at all. In making the statement " $\mathrm{X}$ is good," one was merely expressing how he felt about something and/or attempting to influence others to adopt a similar positive attitude toward it. "Goodness" as an entity had no ontologicai status for the emotivists. As a result, reasoned agreement and disagreement in ethical matters became impossible. The "is" was completely divorced from the "ought" despite Stevenson's reference to a "descriptive element" in ethical judgments. Causes, but not reasons were all that could ultimately be given for ethical juagments: "A reasoned agreement. . . is theoretically possibly only to the extent that agreement in belief [as to what are the actual, 
empirically verifiable facts of the matter] will cause people to agree in attitude." 32 stevenson did not maintain that agreement of the former sort necessarily led to agreement of the latter sort. When and under what conditions this occurred would be a matter for sociology and psychology to explore.

The uninhibited ethical relativism which such a noncognitive approach naturally led to was a source of discomfort for a number of later analysts. R. M. Hare attempted to narrow the gap between fact and value with his "good reasons" approach to ethics, but came under fire from Foot and others for failing to make clear why certain facts instead of others should serve as reasons for evaluative statements. Shortly thereafter John R. Searle burst upon the scene with his startling (to those in the analytic tradition) claim that "ought" (evaluative) statements could indeed be derived from "is" (descriptive, factual) statements. Indeed, he spoke of the "naturalistic fallacy fallacy" in this conrection. Henry Veatch comments that "any suggestion that an 'ought' might be derived from an 'is' would appear at once to revive the possibility that there are such things as natural laws and natural norms after all. Since a law is nothing but a prescribing or prohibiting of certain actions, it would surely seem to follow that if a law were held to be natural las a consequence of its derivability from statements of fact], such a prescribing or prohibiting must itself be something natural, something that is justified literally by the nature 
of the case." 33 Ir assessing the impact of his derivation of "ought" from "is" upon moral philosophy searle himself claims to have cut the ground out from under any argument against deriving ethical statements from sets of statements of fact which is based upon the more general proposition that evaluative statements (of which ethical statements are regarded as a sub-class) can not follow from statements of Iact: "The naturalistic fallacy as applied to ethics is just a special case of the general naturalistic fallacy. I have argued that the general claim that one cannot derive evaluative from descriptive statements is Ealse." 34 while there is considerable question as to whether the Moorean "naturalistic fallacy" involves the derivation of evaluative from descriptive statements, it is at least clear here that Searle's point is to deny the impossibility of such a derivation.

The reason that we are interested in Searle for the purpose of this thesis now becomes clear. It is not as a ceveloper of a systematic ethics that he requires our attention, but rather as a propounder of a meta-ethical position with implications for the possibility of a secular objective ethics. If moral laws or obligations are somehow prescribed by rature itself, we would clearly have an objective ethics independent of any transcendent source. That searle's derivation of an "ought" from ar "is" does not lead to such a situation (nor is it apparently intended to) will now be shown. 
Searle sets out to disprove the thesis, by means of presenting purported counter-examples, that no set of descriptive statements can entail an evaluative statement. There are two somewhat independent instances that we shall consider. (Other examples are of the same type as the first.) searle begins by attempting to show that the expression "valid deductive rgument" can be defined in purely descriptive terms, and that a description of a deductive argument can entail that it is a valid deductive argument. The reason that such a demonstration, if successful, will serve as a requisite counter-example is that Searle, along with J. o. Urmson (with whom he is disputing concerning the counter-example), both agree that "valid" is an evaluative expression. We can accept this claim in view of the connotations typically evoked by "valid" in this context: good, worthy of approval, etc. Thus if it is possible to give a definition of "valid deductive argument" using only descriptive, non-evaluative expressions, then such a definition will entail an evaluative statement of the form "X is a valid deductive argument." The same point is also made by providing a non-evaluative description of a deductive argument which entails that it is a valid deductive argument. Searle proceeds as follows:

" $\mathrm{X}$ is a valid deductive argurient $=\mathrm{df}$. $X$ is a deductive argument and the pre- "35
mises of $X$ entail the conclusion of $X . " 35$

He then provides the following description of an argument which entails that it is a valid deductive argument: 
" $\mathrm{X}$ is a deductive argument in which the premises entail the conclusion." 36 Has searle here given us an instance of a descriptive statement which entails an evaluative one? Lest someone claim that "entails" is an evaluative expression Searle is prepared to substitute furtier descriptive expressions for this term (e.g., "The premises are logically sufficient for the conclusion." "It is inconsistent to affirm the premises and deny the conclusion.") Any of these alternate descriptions, Searle maintains, would entail the evaluative statement " $\mathrm{X}$ is a valid deductive argument." I almost find it hard to believe that searle is serious with this whole procedure. Granted that "valid" is an evaluative term in the sense indicated above. He then defines this term using such expressions as have already been noted (e.g., "The conclusion follows logically from the premises" and claims that the substitute expressions are purely "descriptions" which have no evaluative force. I fail to see how one side of a tautological expression can have the property of being "evaluative" while the other side lacks this same property. While the evaluative force of "valid" is present more on the surface, so to speak, than it is in the case of the alternate expressjons (the evaluative connotation is more immediately obvious), this is not a reason for denying its presence in the substitute phrases. In each case a favorable evaluation of a procedure conforming to the rules of inference of the classical syllogism is implied. To claim 
that "valid" is evaluative and at the same time deny that the alternate expressions are, in the same sense, likewise, is as far as I can see no more than sleight of hand.

Essentially the same conclusion could be arrived at by viewing searle's argument from another perspective. If the descriptive exressions which he has substituted for "valid" (e.g., the premises are logically suficient for the conclusion) are seen as having no evaluative connotation, we may ask how "valid," which is defined in terms of them, can have such a connotation. It would appear that searle is making use of two meanings of "vaiid" in this case, one which is purely descriptive and another which has an evaluative sense. He then makes an illicit slide from the former meaning to the latter when he claims that the evaluative expression can be defined strictly with non-evaluative terminology. All he has actually done is to define a non-evaluative "valid" in terms of another non-evaluative, descriptive phrase.

searle's more famous purported counter-example is his attempted derivation of an "ought" statement from a descriptive ("is") one. This derivation, well known in the relevant literature, is as follows:

1. Jones uttered the words "I hereby promise to pay you, Smith, five dollars."

2. Jones promised to pay Smith five dollars.

3. Jones placed himself under (undertook) an obligation to pay Smith five dollars. 
4. Jones is under an obligation to pay Smith five dollars.

5. Jones ought to pay smith five dollars.

In the version of the derivation presented in speech Acts Searle suggested prefacing each of the five statements with the expression "at time $t$ " to avoid encumbering the proof with a ceteris paribus clause between steps 3 and 4 , and again between 4 and 5, noting that he wanted to "leave out of the proof any explicit consideration of how extraneous factors release, discharge, or override the obligation undertaken when one makes a promise." 37 It is not clear that this move completely obviates ceteris paribus considerations (e.g., at time $t$ Jones may have uttered his well known words while fully aware of important factors which militated against his paying smith the five dollars), but we shall not pursue this point.

I am prepared to concede that, in a way (to be discussed below), Searle's derivation succeeds. I shall not get embroiled in the technical criticism of the proof, but rather, taking my lead from Veatch focus upon its import. Specifically, just what sort of "ought" does searle end up with in step five is the question to which we shall direct our attention. First, however, a few comments on how he gets to step five. Except for the move from step one to step two (where an additional empirical premise affirming the existence of all necessary and sufficient conditions whereby the uttering 
of the prescribed words does indeed constitute the making of a promise) all the earlier steps directly entail the one immediately following, although for formal neatness searle is willing to add appropriate tautoloyical premises. For example, searle points out that on the basis of his analysis of promising it is "by definition, an act of placing oneself under an obligation." 38 The appropriate tautological premise would be: "All promises are acts of placing oneself under (undertaking) an obligation to do the thing promised." 39 In similar fashion Searle moves from step three to step four, and then from four to five. The relevant tautologies are, respectively: "All those who place themselves under an obligation are (at the time when they so place themselves) under an obligation" 40 and "if one is under an obligation to do something, then, as regards that oblication, [my emphasis] one ought to do what one is under an obligation to do." 41 We are now in a position to see just what sort of "ought" Searle has left us with, ard what it has to do witi moral philosophy. That it is a rather peculiar sort of "ought" is indicated by searle's acknowledgement that "I may be justified in not doing what I ought to do as regards a particular obligation." 42 In fact he refines step five in his discussicn of the derivation to read: "As regards his obligation to pay Smith five dollars, Jones ought to pay Smith five dollars." 43 obviously, this does not mean, as searle agrees, that, all things considered, Jones ought to pay 
Smith five dollars. The "ought" is relative to the existence of the obligation. This obligation is what searle would call an "institutional fact," and the point of his counterexample "is to show that the classical model [whereby it is impossible to infer an evaluative statement from a descriptive statement or statements except where the inference is mediated by an additional evaluative statement] is incapable of dealing with institutional facts." ' Institutional facts "are indeed facts; but their existence, unlike the existence of brute facts, presupposes the existence of certain human institutions. It is only given the institution of marriage [for example] that certain forms of behavior constitute Mr. Smith's marrying Miss Jones." 45 Institutions are, for Searle, systems of "constitutive rules." These are rules which actua: ly make possible or constitute a given activity rather than merely regulating activities which exist independently of the rules. He cites the rules of chess, football, and other games as examples of constitutive rules, and the rules of etiquette as an instance of regulative rules. Promise making is seen by searle as an activity governed by constitutive rules. Thus he compares the question, "How can making a promise create an obligation?" to the question, "How can scoring a touchdown create six points?" noting that "as they stand both questions can only be answered by citing a rule of the form ' $X$ counts as $Y$. " 46

Returning to the derivation of Jones' "ought," Searle notes that he 
"...started with a brute fact, that a man uttered certain words, and theninvoked the institution in such a way as to generate instituticnal facts by which we arrived at the conclusion that, as regards his obligation, the man ought to pay another man five dollars. The whole proof rests on an appeal to the constitutive rule that to make a promise is to undertake an obligation, and this rule is a meaning rule of the 'descriptive' word 'promise." 47

Thus to state an institutional fact (e.g., Jones made a promise) "is already to invoke the corstitutive rules of the institution" 48 which, in the case of searle's example, place Jones under an obligation requiring that he "ought" to do what he has promised to do: "if a person promises he is committed to doing the thing promised, and this is purely in virtue of the [institutional] meaning of 'promise." 49 This commitment exists because the person making the promise has implicitly accepted the institution for, if you will, "game") of promise making. That is, he has agreed to "undertake to use the word 'promise' in accordance with its literal meaning, which literal meaning is determined by the internal constitutive rules of the institution." 50 But has he, or has he merely uttered words with the intention of making others believe that he has so agreed?

From the above aiscussion we can see that the "ought" Searle has derived is a purely institutional one. No consideration has been given in the course of its derivation to extra-institutional facts and values. In view of the fact that human institutions are constituted by rules or 
conventions, his "ought" is conventional. Searle cannot (nor does he intend to) give us any criteria by which we can determine whether or not his "ought" ought to be adhered to. This would involve questions external to the institution, and he has provided no way of addressing them. Searle acknowledges this point:

"Nothing in my account commits one to the
conservative view that institutions are logical-
ly unassailable or to the view that one ought to
approve or disapprove this or that institution.
The point is merely that when one enters an insti-
tutional activity by invoking the rules of the
institution one necessaril commits oneself in
such and such ways, regardl. ss of whether one ap-
proves or disapproves of the institution. In the
case of linguistic institutions, like promising
(or statement making) the serious utterances of
the words commit one in ways which are determined
by the mearing of the words." 51

This at least would be the prima facie expectation generated on the part of one's hearers by somebody who uttered a promise under conditions which caused the utterance to be seen as "serious." However, just as Searle's linguistic conventionalism provides no means of evaluating institutions en bloc, it likewise provides no way to approve or condemn a practice of selective conformity to them. Take the individualistic egoist, for exarple, who chooses "J use the institution of promising (and other institutions) to his best advantage, keeping his promises when this suits his purposes and disregarding them when he finds this course more advantageous. He places himself above the institution, neither 
approving nor disapproving it per se, but viewing it as something to be taken actantage of for his own ends. For instance, the general expectaion that promises will be kept will prove useful in having his own believed. Thus it is not quite true that "by invoking the rules of the institution one necessarily commits cneself in such and such ways." One may intentionally invoke the rules of the institution insincerely for one's own purposes. The commitment of which Searle speaks may never be made. Since searle is fond of comparing institutions constituted by linguistic rules with games which are constituted by rules prescribing certain forms of behavior, the following illustration may be fruitful. Consider a baseball pitcher who can get batters out more effectively when using an illegal pitch. When it is to his advantage to do so (when he can get away with it) he throws this pitch. When the umpires are on the alert to look carefully for it, however, he refrains. The fact that he has engaged in the institutional activity of playing baseball is prima facie evidence that he has committed himself to behaving in accordance with the rules of the game. That this is not necessarily the case we have pointed out. Furthermore, as long as he takes the stance that he is above the institution, obeying its rules only when this suits his purpose, like the individualistic egoist he cannot be called to account (except within the framework of the institution) on the basis of rules which are entirely internal to the institution. In order to do 
this a meta-institutional principle to the effect that "whenever one explicitly or implicitly makes a commitment to abide by the rules of an institution, one should honor that commitment" would be required. Such a principle is not available to searle, and thus he has no grounds for disapproving the egoist who plays fast and loose with institutional rules. Searle's "ought" is a purely conventional one, having no objective status beyond the bounds of the relevant conventions, and, as we have seen, he provides no criteria for evaluating conventions. His "ought" is not to be found in nature; as Veatch puts it: "..just as the binding or obligating character of rules in baseball by no means implies that such rules must be on the order of natural law, so also the mere fact that certain linguistic rules authorize the derivation of a moral "ought" from an "is" in no wise entais that such "oughts" must be natural "oughts" or "oughts" determined by anything like natural laws." 52 searle's contention that he has refuted the main traditional argument against the possibility of deriving ethical statements from factual, descriptive ones by demonstrating that evaluative statements (of which ethical statements are a sub-class) can be derived from purely descriptive ones must be seen with this in mind. He has, in the last analysis, provided no more of a refutation of the institution manipulating egoist than did Taylor. The immediately preceding discussion is not intended to imply that searle's derivation fails on the institutional 
level. That is to say, it is here acknowledged that his institutional obligation ("ought") has been successfully derived from the initial statement of Jones plus the invocation of the relevant constitutive rules and the additional premise relating to the serious intent of Jones to in fact utter a promise. What I am calling into question is the significance of the derivation for ethics. To the person who places himself "above" the institution it has little significance, and for ethical principles to be established as objective in a meaningful sense of the term some rebuttal to the individualistic egoist (or other subjectivist) would appear to be required. In the case we have been considering such an individual, who views institutions as tools to be utilized for the furtherance of his own ends, may freely accept searle's derivation without it having the sightest impact upon his meta-institutional position. Possibly, Searle would agree with this; in that case, however, are his results not trivial as far as the development of actual ethical norms binding on all persons (regaraless of their institutional affiliations) is concerned? The sort of "ought" that searle has derived from an "is" does not appear, in Veatch's words "to revive the possibility that there are such things as natural laws and natural norms after all." (See footnote No. 33.) In whatever (institutional) sense of the term Searle has derived "objective" ethical precepts, it is not in the sense of "objective" that we are concerned with in this thesis. 
If Searle is not attempting to derive "objective" ethical norms in my sense of the term, why have I bothered to critically examine his derivation of "ought" from "is"? The reason is that his work has been seen by some as pointing toward something more than the merely conventional "ought" which we have discussed. Veatch for one talks about the possibility of interpreting Searle, "at first glance," as attempting to lead the analysts into the camp of the naturallaw philosophers! Searle's work can, I think legitimately be seen in some sense as a reaction against the more extreme subjectivist tendencies of earlier analytic ethical philosophers (e.g., the emotivists). Part of the problem of interpretation lies with Searle's first version of the "ought" from "is" derivation published in the Philosophical Review. We have not examined it here since searle himself regarded the later version in Speech Acts as superior. The difficulty Iies in the fact that the ceteris paribus considerations, left out of the Speech Acts derivation proper, were incorporated within the earlier version. Thus two senses of "ought" were involved, the purely institutional "ought" and a metainstitutional one. It is not difficult to see how they could be confused, with the consequence that searle could be taken as arguing for (or at least hinting at) the possibility of establishing a much wider thesis than the merely institutional one he more clearly argues for in the Speech Acts version of the derivation. Be as it may, the essential point that I want to make is that in no way can Searle's "ought" be 
legitimately held to have significance outside of the narrow institutional framework within which it was derived.

SARTRE: GOOD FAIIH

At first glance it may appear strange to consider Sartre or any writer in the non-theistic existentialist tradition in a thesis dealing with purportedly objective ethics. As far as Sartre in particular is concerned, does not his famous dictum that man is a being in whom "existence precedes essence" (an ontologically "free" being--contingent, undetermirad, and beholdin to nc a priori values) rule out the F.ssibility of any sort of objective etrical norms? Is it not the case for Sartre that all values and distinctions between right and wrolg originate in the absolutely free resolves of human subjects with the consequence of a complete inter-subjective relativity of morals? While such conclusions may appear at first sight to be necessary, Sartre himself does not consistently draw them. Rather he makes some startlingly apodictic ethical pronouncements concerning one's obligation to make moral choices in "good faith" in a manner which respects the concrete freedom of others. At this point I should note that I am considering only Sartre's early, existentialist thought, with no notice given to his later, Marxist notions. Specifically, I am concerned with Sartre's ethics up to and including the 1946 essay, The 
Humanism of Existentialism. In ethics, as in other areas, his early thought revolves primarily around an individual, self-interest perspective.

For Sartre the ontological freedom, noted above, is basic for man, and in no way stems from or depends upon his interaction with others; however, he draws a surprising conclusion from or perhaps in spite of this dictum: "Of course, freedom as the definition of man does not depend on others, but as soon as there is involvement, I am obliged to want others to have freedom at the same time that I want my own freedom. I can take freedom as my goal only if I take that of others as a goal as well." 53 There is a confusion between an ontological position and a normative, ethical one in this sentence, an attempt, as it were, to derive an "ought" from an "is," something Sartre himself rules out of court in Being and Nothingness where he states that "ontology itself cannot formulate ethical precepts" 54 because "imperatives" cannot be derived from its "indicatives." As far as abstract, ontological freedom is concerned, sartre holds that we have it whether we want it or not. Furthermore, it is certainly not true that one must want it, either for himself or for others. Indeed, sartre himself points out that this freedom is a source of anguish and despair, and that most people would prefer the comfort and security of absolute a priori essences and values even while, contradictorily, desiring the freedom to create their own essences. This is the 
desire to be a being-in-itself-for-itself; as Hazel Barnes puts it: "They wish to realize the freedom which distinguishes them from things and the other creatures in nature and at the same time to possess their absoluteness. " 55

Where concrete freedom enters the picture (e.g., freedom of movement, political freedom) it is not at all clear why one should want it for others even on the assumption that one wants (has chosen it as a value) for oneself. Yet Sartre asserts with respect to concrete freedom in the context of engagement with others that one can take his own freedom as a goal only if he takes the freedom of others as a goal also. Barnes attempts to make a coherent argument out of Sartre's manifesto-like pronouncements to this effect in I'Existentialisme est un humanisme. She puts it as follows: "Since I recognize that freedom is my essence, both as myself and as a human being, I cannot truthfully deny that the same is true for all other persons. Their freedom is as much a part of the data as my own." 56 This argument says, in effect, that if I am free by virtue of the fact that I am a human being, it must follow that all other human beings are also free. Affirming the antecedent, Barnes concludes the consequent. There is something suspicious, from an existentialist standpoint, of talking about freedom as "my essence," since Sartre strongly denies the existence of any fixed human essence. It would have been better had Barnes referred to freedom as the ultimate existential reality of the human condition. This, I believe, is what sartre 
meant when he referred to freedom as the "definition of man," acknowledging that this formal freedom does not depend on the other in any way. This is not, however, the crucial fault of Barnes' argument; the problem lies rather in an illicit slide from abstract, ortological freedom (the human condition) in the artecedent to concrete freedom of action for other persons as an implication cf the consequent. This is seen in the immediate continuation of the above passage: "therefore [my emphasis] if I declare that the development of my own free projects is the goal and good of my life, I must--if I am in good faith--allow simultaneously that my freedom holds no privileged place over this assertion when it is made by someone else."57 It is one thing to affirm in "good faith" that in the absence of God all men are existentially free-- undetermined, contingent, and beholded to no a priori values. It is something quite different to maintain that any given individual, in acting concretely under these circumstances, has an obligation to respect a concrete freedom of action on the part of others. Slice it as you like, the second does not follow from the first. Thus Barnes has failed to show that sartre's ontological freedom entails any responsibility toward others; if her elaborated formulation of Sartre's L'Existentialisme est un humanisme argument is a valid representation of his position (and I believe that it is), then it follows that sartrean existentialism fails to refute the egoist's proclaimed right to use others strictly as objects 
to facilitate the achievement of his own freely chosen goals. It avails the defender of sartre nothing to appeal at this point to the failure of those who seek to "use" others to achieve their purported ontological purpose, the appropriation of the other's transcendent freedom. It is not necessary to attempt to untangle the complex web of Sartrean notions of being-in-situation with others in order to make the basic point, once again, that whatever the ontological situation, it cannot, in and of itself prescribe ethical "ughts." It may be unavoidable that we encounter and interact with the being-for-itself of others; it does not follow from this that we have a duty to somehow respect the other's subjectivity. The Dutch philosopher, Luijpen insists that "The other's right is the minimum of my 'yes' to his subjectivity." 58 Veatch responds "...just why should I or anyone else imagine that he is in any way bound to say 'Yes' to another's subjectivity. Why not say "No" to it, and be damned!"59

Respecting the concrete freeciom of others is a "good faith" choice for sartre. We have seen that he fails to make a convincing case, on existentialist grounds, for the existence of a moral obligation to choose this freedom. The same sort of argument that we have employed with respect to the specific "good faith" choice of the other's freedom may be brought to bear on the logically prior question: Why should we choose in "good faith" at all? Why not choose in "bad faith"? It will be recalled that to choose in good faith 
is to choose in a manner which recognizes and is faithful to man's existential situation. That is, man is seen to be left alone in the world to provide meaning and purpose for his existence. There is no God to provide values, no inevitable historical determinism to obviate individual choices, no fixed human essence to provide a source of a priori goals, and no necessity of existence of any individual person. If one accepts all of this ontological baggage there still does not follow any moral "oughts" concerning one's choices of actions and world views. If one chooses to act as though God exists and has handed down revealed values to guide human conduct, the worst that a sartrean existentialist is entitled to say about him is that he is in error in being inconsistent with himself. There are no existentialist grounds for claiming that one "ought" not act in such a way. If, for example, someone who shares Sartre's ontology nevertheless says that he finds his life more satisfying by acting as if there was a God, Sartre has no basis for condemning him on ethical grounds. Veatch discusses this problem in the following passage:

"The challenge was that the existentialist must show the grounds on which it might be supposed that iny human subject was under an obligation--a moral obligation--to make authentic choices. Apparently the answer to this challenge took the form simply of pointing out that man is a free being, and then going on from there to exfoliate just what is involved in such a notion of freedom. Yet how, from the fact that man is free in his choices, is one able to infer that he is under an obligation to make his choices in a certain way? or, put a little differently, supposing that man is free, why 
should the mere fact that he is so make it wrong for him to pretend that he is not, or to try to conceal from himself his true concition? Is this not to derive an "ought" or an "ought not" from an "is"? And does this not go diametrically counter to what we have seen was the initial step which the existentialists, no less decisively than the analysts, would appear to make? It was just the step of proclaiming, to borrow Olafson's words, that 'no property that a situation might be discovered to have could possibly determine by itself the value of that situation.' How, then, from the fact that the existentialist fancies that he has discovered that man has the property of being free can he infer that man is under obligation to make choices in full recognition and acknowledgement of that freedom? . . . Surely, if an existentialist makes a move of this sort, then his ethics is indeed, if not a natural-law ethics in the usual sense, then at least an ontologically grounded ethics." 60

There is an interesting similarity between Sartre's argument and that of Gerwith, examined earlier. Where Gerwith failed to show that normative rights to concrete freedom and well-being follow from the putative definition of man as a prospective, purposive agent, sartre failed to ground similar rights in a definition of man as an ontologically free being. Both arguments are unsuccessful attempts to derive an ethical "ought" from an ontological "is."

\section{VEATCH: AN ONTOLOGY OF MORALS}

Veatch agrees with us in rejecting the three meta-ethical theories which we have examined to this point, maintaining that theories of goodness and moral imperatives which are without an ontological basis must inevitably lead to rela- 
tivism and "nihilism." Since egoism may be regarded às a species of relativism (unless a fixed or constant human nature is assumed), this implies that they are internally unable to meet the challenge of the individualistic egoist. The authors of each of the three theories we have so far considered all attempt, in various ways, to derive a moral obligation to respect a certain right or rights of others. However, on the basis of their own initial assumptions (or axioms, if you will) they are unable to bring this off. Thus the egoist or relativist can undermine their theories from within, and such subversive activity can be countered only by further, ad hoc, moves. Veatch, in contrast with the above theories, seeks to place values (goodress) on an objective footing by demonstrating that they have an ontological status in nature or reality as supervenient properties.

In connection with veatch we have beer bandying about rather loosely such expressions as "ontology of morals" and "ontological status." It is time to say something about what we mean. As will quickly become apparent, "ontolcgy" for veatch is quite different from what it is for Sartre. Let Veatch speak for himself: "... why not frankly acknowledge that for anyone to take ethics as somehow presupposing an ontology is indeed to imply that moral and ethical distinctions--distinctions between good and bad, right and wrong, ought and ought not, etc.--are somehow grounded $i$ : the very being and nature of things?"61 Elsewhere he comments: "We 
are us:'ng the expression 'ontology of morals or ethics' to signify just that type of ethical theory which seeks to 10cate ethical and value distinctions in the facts, independently of their being desired, and not as a mere function of their boing desired."62 In another passage we read: "... in inquiring as to the 'ontological status' of goodness, we rean to inquire as to the objective and, in this serse, indef ndent status of goodness as it is in the world and apart from us human beings and our feelings and reactions to things."63 Finally, veatch describes "the ontology of natural law" as irvolving a claim for "an objective status in nature for things like norms, standards, values, laws, etc."64 It will be seen that veatch uses the term "objective" in the same way in which I loosely defined it near the beginning of this thesis.

In his book, For an Ontology of Morals, Veatch attempts to answer what he considers stock objections to the possibility of an ontology of morals. He then goes on to sketch the outiines of such an untology in terms of an AristotelianThomistic notion of the actualization of potentialitias. Following this, he makes a few comments on the episternology of morals. I shall comment only briefly on the iirst of these steps, limiting myself to expositicn. The secorid step shall recuire a critisal examination, while the third shall serve as a trarsition to the last section of this tiesis. T.e first objection $t$ the possibility of an ontology of 
morals which Veatch considers is based on Moore's "open question" argument. This challenge argues from the purported indefinability of goodness to its unreality. That is, if goodness cannot be defined in terms of the existing entities and characteristics thereof found in reality, how can it have any reality of its own? (While Moore, himself, did not draw such a conclusion from his "open question" argument, holding rather that goodness was a "supervenient property," later, analytical philosophers did.) Veatch counter-attacks by rejecting what he sees as a Moorean analyticity requirement for definitions, holding that "If one thinks of definition in a common-sense way as being nothing but a desire for stating what essentially this, that, or the other given thing is, then immediately it becomes clear that there just aren't any definitions in this sense that are not open to question." 65 "Real" definitions, claims veatch are always capable of being doubted, since fallibility in describing and delimiting the essence of things is unavoidable. Thus veatch holds that he has cleared the way, in principle (at least as far as this objection is concerned), to defining goodnes's "directly in terms of certain of the features or properties of the real worla." 66

The second objection to the possibility of goodness being an objective quality or property of things revolves around the notion that it must involve some sort of responses on the part of a subject (e.g., desiring, approving, commend- 
ing, etc.). Thus Hare objects that if calling something "good" means no more than ascribing certain specifiable, objective properties to it, then it would be impossible ever to use "gooä" as a term of comendation, a connotaticn which, language use teaches us, belongs to the term. If, for example, to call a strawberry "good" simply means that it is siret, red, juicy, etc., then one could never commend a strawber y that had these properties by calling it "good." Hare concludes from this that rather than being an objective property of things, goodness is found to stem from subjective responses to things.

In order to be able to understand veatch's response to this second objection, $\bar{i} t$ is first necessary to lock at his concept of the actual ontological status of goodness. Veatch holds, in accordance with the Thomistic tradition, that goodness, like being, is to be found in all of the Aristotelian categories, and consequently is not definable per genus and differerce. He then points out that the "act-potency distinction" is a basic tenet of Aristotelian meta-physics, and draws an analogy between this dyad and the following ones: perfect-imperfect, complete-incomplete, developed-undeveloped:

"...insofar as I am not actually informed about something or other, but only able to be so; or insofar as the seed is able to sprout and grow and develop into the full-grown plant, but has not autualiy done so; or insofar as the coiled spring ras a potential energy, although there has been no actual release of that energy--in all such cases a potentiality or mere capacity 
may be compared to the corresponding and correlative actuality, as the imperfect to the perfect, the incomplete to the complete, the undeveloped to the developed. It is as if a mere potency just as such somehow bespeaks a certain lack, or imperfection, of which the actuality for its part is simply the fulfillment or completion." 67

On the basis of the above veatch hazards a definition of goodness as "nothing more or less than the actual as compared with the potential, and in the very sense of the perfect or complete as compared with the imp.rfect or incomplete." 68 This definition, veatch believes, allows for an intelligible way of describing goodness as a supervenient property. Thus the empirically observable properties of things can be sources of value or goodness "just insofar as they are properties that evidence the perfection of complete actualicy of the thing in question." 69

We are now in a position to look at Veatch's answer to the objection that goodness must stem from the evaluative response of a subject or subjects. He concedes some force to the objection, acknowledging that goodness cannot be considered as "the sort of objective property that simply exists there in the object, in splendid isolation from any and all relationships to a subject and to such pro-attitudes as that subject may evince..."70 veatch rather finds goodness or value to be "itself a kind of relational property, just in the sense that it points up the objective properties of the object as being themselves the termeni of a relation: 
they are but the fulfillment or actuality of a pior potentiality which was ordered to those properties [my emphasis] just insofar as they constitute the fulfillment or perfection of such a potentiality." 71 with regard to Hare's strawberry, veatch maintains that "To call it good is simply to illuminate those objective properties of the berry in a new light, exhibiting them as constituting the perfection and fulfillment of what a strawberry might be and could be and, in the non-moral sense, ought to be." 72 Veatch is attempting to steer between the alternatives that: 1) things are desired simply because they are "good," and 2) things are good only because they are desired. His position is obviously much closer to the first alternative, but is somewhat more involved. Things are desired, for Veatch, becaise they have certain properties and those properties are seen as constituting the actualization or perfection of the thing in question. He rejects the second alternative eltirely on the grounds that it would rule out giving reasons in ethics. To the question, "why do you desire $x$ ?" (assuming that things are good only because they are desired), one could only answer by citing causes, not reasons. Under this assumption value and moral judgments would be reduced to arbitrary preferences from the standpoint of reasons. As in the case of Hare's question as to why $x$ likes spinach, the answer is that he just likes it, that's all. But, Veatch maintains, moral judgments do not fit this model; where they are con- 
cerned reasons immediately become relevant. When we say that something is good we mean something other than that we hav a desire for it (we may mean this also). This is shown by the fact that people frequently acknowledge having desires for things that they would agree are not good. Nevertheless, Veatch concedes that goodness can't be understood without (though it is rot to be defined in terms of this factor) some reference to the subjective factor of desiring, approving, commending, etc. In spite of this he rolds that ethics can still te reasonable. He explains how this is reld to follow from his definition of gooäness: "If one understands goodness as being but the actual as over against the potential, or the perfect toward which the imperfect is ordered [my emphasis], then while goodness is indeed understood as the actual or perfect, precisely insofar as it is desired or aimed at by that wich is still only potential, it still does no: mean that such actuality and perfection are what they are only by virtue of their being desired or aimed at." 73 There is "uch in the way of criticism that could be said concernir 9 Veatch's ontology and definition of goodness. The procedure to be followed here, however, will be to grant him his definition and then ee whether or not it is possible to get an "cbjective" morality or ethics from it. Veatch has denied that actuality and perfection are what they are by virtue of their being desired or aimed at. It is Eair then to ask, just how are they what they are? This question 
is also pertinent to Veatch's notion of natural law which he considers as nothing more than the ordering of potency to its appropriate act (e.g., an acorn is "ordered" to develop into an oak, a tadpole into a frog, etc.). It is one thing to determine empirically that acorns, under certain circumstances, develop into oak trees, or that strawberries, under appropriate conditions, become red, sweet, and juicy. It is something quite different to say that these are their respective perfections or actualizations, and that they, nonmorally "ought" (whatever this means) to attain such states. In order for certain states of trees, strawberries, men, etc. to be considered as perfected or completed states, is it not necessary to posit a creator-designer who has "ordered" them to such states? Otherwise, for example, on what grounds do we call a fully developed, healthy, fruitful tree more perfect than a stunted, diseased, barren one? Certainly not (for Veatch) because the former is more aesthetically appealing and desirable from the standpoint of human subjects. That a certain state of something is regarded as the "perfected" or "completed" state of that thing implies that some consciously purposive being has designed the thing in question and intended that it should culminate in that state. These notions fail to make serse otherwise. Veatch appears to feel this in two passages which have already been cited where I underlined the references to the ordering of the potential or imperfect. surely such ordering implies an orderer. In his discussion of natural laws 
Veatch thinks that in "determining the exact ontological status of laws as they exist and are operative in the real world, we may happily disregard the question of the origin of the law--i.e., law as it is the mind of God or of the lawgiver (in mensurante)--and confine our attention simply to law as given and hence as it exists in fac: and in nature (in mensurato)."74 But a "law" without a lawgiver is no law at all. Veatch leaves us with nothing more.than inductive generalizations, and he would be among the first to tell us that one can't get an "ought" (moral or "non-moral") from these since he agrees with Hare (against searle) that an evaluative sense must already be incorporated in a key factual premise in order to derive an "ought" from an "is." Where is such an evaluative sense to be found without an orderer, a lawgiver? Certainly not in inductive generalizations dealing with the biological development of seeds, acorns, etc.

Veatch's interest is in morality, not biology. Consequently it is when he turns to man in his attempt to apply his Aristotelian-Thomistic scheme that we must pay the closest attention. The key questions to be addressed are: 1) what are the actualities/Eerfections of men qua men?, and 2) how do we know we have answered the first question correctly? veatch makes reference to wat he calls the standard of human nature which "is the sort of thing that must serve as our standard in the pursuit of such humanistic learning as is relevant to ethics." 75 However, he is not very clear on 
just what this standard is. In one place he defines it as "that of being a rational animal." 75 This does not tell us much about what man, ethically, "ought" to be--what sort of ottributes and behavior patterns are the moral paradigms for man. That is, it doesn't tell us much in itself. If veatch is using "rational" in a wider sense than that of conformity to the laws of logic (and I think that he clearly is), t? a we must determine what are the particular human attributei and behavior patterns which re subsumes under this ruticic. Furthermore, we must determine if Veatch is entitled to do so on the basis of his "ontology of morals." Fortunately, he gives us examples of the human attributes and behaviors which he considers as paradigms of the actualization of man qua man. In this regard, for example, Veatch cites with approval the bravery and "real sense of justice" exhibited by Socrates in refusing to obey the Atheniarn oligarchy of the Thirty when they ordered him to participate in forcibly bringing into their hands an individual whom they warted to execute. Elsewhere Veatch refers to the alleged fact that "all men in their infancy have a potentiality to become mature, intelligent, and responsible adults" 76 (obviously ignoring genetic determination to the contrary in some cases, at least with regard to the intelligence factor--e.g., Down's Syndrome). In anotier place he refers to wisdom, a sense of justice, courage, and self-control as "achievements, accomplishments, perfections, which represent but so many 
actualizations of the [a particular] man's prior potentialities." 77

It will be recalled that veatch has defined goodness or value as the actual or perfect. He has then pointed to certain at least in part empirically determinable characteristics which he considers to be actualizations or perfections of man qua man. Why should we believe him in this regard? If, without a lawgiver, his case rested on shaky grounds where acorrs and tadpoles were concerned, it would appear to rest on even shakier grounds where man is concerned. In the case of nature we could at least rely on fairly accurate inductive generalizations concerning how acorns, tadpoles, etc. actually develop, physiologically, under certain specifiable physical conditions. Furthermore, such development doesn't require any "cooperation" on the part of acorns, tadpoles, etc. Thus it makes some sense, in a restricted use of the term, to talk about "natural laws" in such cases. In the case of man, however, veatch is dealing with ethical norms and development, not with purely physiological processes which take place independently of any volition on the part of the developing subject. Yet he believes that the same concept of natural law is equally applicable in both cases: "It makes no difference whether these natural laws which thus determine the order of potencies to acts are laws that need to be consciously recognized and acted upon, or whether they be laws that are oferative independently of their being known; in either case they are nothing 
other than a natural order.ng of potencies to acts, and as such their ontological status is the same." 78 In what sense, we ask, is a rule or "ordering" which must "be consciously recognized and acted upon" a natural law, and one with the same ontological status as those "laws" which operate mindlessly in nature? While, in the absence of a creatordesigner source for such laws, I can make some intelligible sense out of the term "natural law" when apolied in the lat$t: \because$ case, I can find no such sense for this expression in the former case.

We may look at the problem from a slightly different angle. In the case of a man who fails to realize his actualization or perfection (in terms of becoming "a mature and responsible adult") his life is, for Veatch, "if not a downright failure, then at least not what it mignt have been or ought to have been." 79 Just what sort of "ought" is this, and where coes it come from. If it is a "non-moral ought" (Veatch's term, see above) then it would appear that the operative "natural laws" do not prescribe moral imperatives, and are therefore irrelevant to ethics. If, however, veatch intends a moral "ought" here (as appears more likely) the question is, where does it come from? Why should one be morally obliged to actualize his potentialities (assuming that it can be determined what these are in the first place) as this requires purposive effort which might be expended in innumerable other ways? In the absence of a creator- 
designer who has moral authority over his creation, I can find no intelligible answer to this question. Why not be indifferent to the "natural end" of man?

Let us return to the matter of Veatch's candidates for actualizations or perfections of man qua man. of these we have noted, "a sense of justice" is certainly a key where ethics is concerned. In view of the fact that veatch has defined goodness or value in terms of actualization, we may ask just what is this "justice," a proper sense of which he refers to as an actualization? Certainly "justice," whether conceived retributively or distributionally, is a concept which is intimately connected to that of right and wrong. It has to do with people getting "what they deserve," "what they have coming to them," "what they have earned," "what they are entitled to," or some such notion. While strict deontologists are apt to maintain that "right and wrong" is the fundamental ethical distinction, even they would acknowledge its intimate connection with that between good and evil, and Veatch is not a deontologist. Thus it seems unavoidable that his notion of justice can be explicated only in light of some idea of goodness, with the result that, with respect to this particular "actualization," his definition process is quite circular. One needs to have some notion of "goodness" in hand before talking about "justice," yet veatch has, in part and with respect to human attribites, defined the former in terms of the latter. Similar argu- 
ments could be constructed with respect to at least some of his other putative human actualizations.

We have seen with respect to the other ethical theorists whom we have considered that they all wanted to incorporate some type of egalitarian principle into whatever full fledged system of morality would emerge from their initial meta-ethical and/or ethical axioms, but that they were unsuccessful in so doing except by means of an ad hoc maneuver of some sort. Thus Taylor could not derive a duty ever to subordinate the fulfillment of one's desire to that of another from his notion of goodness; Searle could never get beyond his "institutional" obligations to keep one's promises (although in his case it is not as clear that he consciously sought to do so); and sartre was unable to justify, on the basis of his own ontology, an ethical requirement to respect the concrete freedom of others. The case with veatch in this respect is similar. While he does not spell out moral requirements to respect certain rights and freedoms cf others in terms of formal principles, it is clear from certain of his examples, particularly the one concerning Socrates' "real sense of justice," that his concept of the actualized or perfected man includes a requirement to behave in such a fashion. We have already seen how he fails to bring off his scheme of natural laws pertaining to human actualization, in the absence of a law-giver. Thus veatch, on the basis of his own ontology, has no way to refute the 
individualistic egoist who, for instance, conceives of his own actualization in terms of the maximum satisfaction of his personal desires regardiess of what this costs in terms of the frustration of the desires of others. It would even be difficult to find a "ratural law" for human actualization in the purely empirical-inductive sense which we agreed makes some sense in animate nature, there being so many variant goals and desires among human beings. Furthermore, even if the egoist agreed with Veatch that there was some "ratural end" for man, Veatch has not, in the absence of a law-giver with moral authority over man, provided a cogent moral argument to the effect that the egoist ought to pursue this end.

In fairness to Veatch it should be noted that none of the preceding critical discussion implies that he sought to establish an ethics which is independent of God in the order of being. Veatch is, after all a theist himself who operates in the Thomistic tradition. What he has done, however, in the work which we have examined, is to follow a pattern of exposition (an "order of knowledge," if you will) in which he purposely precinds from the question of the existence of a personal law-giver as the source of his "natural laws" for the development of potentialities in man and in animate nature as a whole. I have attempted to show that tis approach leaves something to be desired. Insofar as Veatch fails to make use of his Thomistic ontology (and in 
the work we have examined he generally fails to do so), he does not succeed in making a credible case for the existence of "natural laws" and a "natural end" for man. Where he specifically addresses epistemological questions, Veatch implicitly relies on some sort of intellectual insight. I shall make some comments, on the whole favorable, pertaining to this epistemological methodology in the final section of this thesis.

\section{CONCLUDING EPISTEMOLOGICAL POSTSCRIPT}

In this thesis I have attempted to show that four different non-theistic meta-ethical approaches, each representative of either a contemporary (20th century) or traditional way of doing ethics and/or meta-ethics ( $I$ have avoided the tricky matter of trying to draw a clear distinction between these), fail to lay the foundation for an objective ethics. My method has been to use individualistic egoism (a form of subjectivism) as a foil with which to attack the various attempts of the respective theories to establish as an objective ethical norm some sort of egalitarian principle by which one is morally required to respect the rights (or a particular right) of others. An appropriate question to ask at this point is what advantage, if any, does a theistically based ethics have over the theories we have examined with respect to establishing objective norms for human behavior. 
I am prepared to maintain that, given the appropriate initial assumptions, a theistic system of etrics can be established which contains objective principles. Sucl an ethics will be able, on the basis of its own initial assumptions regarding the nature of goodness and the source of mo al o.ligation, be able to repel the egoist challenge. No ad ho: egalitarian assumption will have to be brought in, one which does not stem from the basic ontological tenets of the theistic ethics. Tris is not a claim that theism and a consequent theistic ethics can be proved, and egoism disproved. Neve.theless, if true, it puts a theistic ethics in a better position, vis-avis egoism and other subjectivist attacks than the other theories we have consiaerea.

In this concluding section I try to indicate how an ethics grounded in the will of a divine being may establish objective norms. I do not attempt to outline such an ethics, nor to demonstrate the existence of Goc; both projects would go well beyond the scope of this thesis. Thus on the level of a clash of initial assumptions or axioms I make no claim to have refuted the egoist or any other non-theistic ethical approach. In this connection I make a few remarks about the justification of initial assumptions; however, a fuli scale discussion of the relevant epistemological questions is beyond the competence of this writer.

Turning to an ethics grounded in the will of a divine being, what sort of initial assumptions need to be made to 
allow the derivation of objective norms? one must, I believe, start from a concept of the dei-y consistent with the classical Judaeo-Christian notion. God is there viewed as an omnipotent, omniscient, and benevolent (good) being who has designed and created the cosmos including man and his world. Goodness is thus seen as an attribute of the divine being, God being the ultimate reference point for questions pertaining to whether $\mathrm{X}$ is good. Therefore, God does not approve of something because it is good independently of $\mathrm{Him}$. In the field of human behavior, it follows that the ethically good is defined by divine commands pertaining to this area. From these initial premises of a theistically grounded ethics it is claimed that objective norms in terms of revealed divine commands may be established. These are then binding on all men, leaving the egoist no way to avoid their force. Might a clever egoist or other subjectivist not ask the following question: granted that such a God exists, does it follow that an ethical obligation to obey Him also exists? Is not an argument to tinis effect just one more attempt to derive an "ought" from an "is"? The answer is that there is an evaluative sense built into the "is" premise affirming God's existence. He has been defined, in part, as the ultimate standard of goodness in whom there is no evil. It follows from this that his commands must be good, and, if "right" is defined in terms of advancing, maximizing, etc. the good, obedience thereto morally right. The stubbon egoist may still ask, why should I do that which is morally 
right? This, however, is a different sort of challenge from the one we have been dealing with. In asking this question the egoist is already implicitly acknowledging that there are such things as objectively good or right actions, and this is all that we are asking from him.

It may still be argued that we have not, on the basis of a theistically oriented theory, established the existence of objective ethical norms. After all, the claim that there are objectively good divine commands and right actiors in con:ormity with these commands does not, by itself, strictly entail the prescriptive statement that "one ought to obey these commands." A further premise, to the effect that the commands of a divine being such as we have described above ought to be obeyed, is needed, and is this not just the sort of ad hoc mar:euver that we have been considering with respect to the secular ethical theories? In a sense it is, but it has, I believe, an advantage in terms of prima facie or initial plausibility over the analogous moves which must be made in order to obtain objective norms from the other theories. This is, that if one accepts the existence of an omnipotent, orniscient, benevolent deity who has revealed his will regarding human conduct, it seems intuitively natural to hold that one "ought" to obey the morally good commands of this deity, the obedience to which are morally right. A similar claim cannot, in my opinion, hold with regard to the additional premises necessary for the derivation of objective ethical norms from 
th: : cular theories which we have considered. An et lical re-

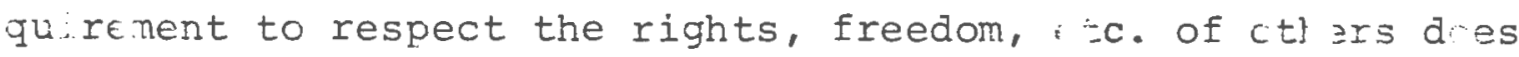
not "flow" from their basic ontological assumptions. In ti.e case of the divine command theory, howerer, if we ag: ee that it is plausible to hold that one ought to obey the commands of the deity, and that among them is to be found a command to "Iove your neighbor as yourself," we have all we need to establish the latter as a moral imperative. I must acknowledge that all I am claiming here is an advantage for a divine command theory vis-a-vis the particular secular theories which we have examined. A wider ciaim to the effect that all secular theories must, in principle, fail in any attempt to establish objective ethical rorms is beyond the scope of this thesis.

If I have argued successfully for the above advantage of a theistically based ethical theory vis-a-vis the secular counterparts which we have examined, at what price is this advantage obtained? In declaring that goodness is an attribute of the divine being, I have said nothing determinate about its nature. This appears to leave me open to the charge that I am using "good" emotively, as merely a term of approbation applied to the deity. In contrast some of the secular theories we have considered (e.g., Taylor and Veatch), whatever their other shortcomings, do give a content-full definition of "good." I am not quite certain what to say in response to this criticism except "so what?" The failure oi" 
inability to specify a determinate nature of "goodness," does not, in itself, entail that the word is being used only in an emotive sense. It may be the case that Moore was correct in holding that goodness is undefinable. If I have been able to make a plausible case for the existence of objective moral norms on the basis of a theistically based ethical theory, one which is noticeably stronger than those which can be made on the basis of the competing secular theories, I don't see why I should be bothered by the failure of the theistic theory to provide a determinate, "definition" (in a Moorean or Aristotelian sense) of "goodness." It may, after all, be the case that one can know what goodness is only by means of an insight into its nature which cannot be precisely communicated by means of propositions. Into this question, however, we shall not delve.

Once more, it has not been the purpose here to argue for the existence of the deity. Questions pertaining to purported philosophical proofs of God's existence and those dealing with his ontological character (e.g., whether an omnipotent, omniscient, totally good God is possible) are far beyond the scope of this thesis. I have been content with the much more modest goal of showing that if the initial assumption of the existence of the Judaeo-Christian deity in terms of whom goodness is defined is granted, then the existence of divinely revealed objective ethical norms (assuming that God deigns to reveal such things in propositional 
form) follows. If this is true then a divine ordinance theory of ethics has a distinct advantage over the competing theories we have examined, if the establishment of objective ethical norms is taken as a goal.

If it were to be granted that objective ethical judgments are possible only if a divine source is postulated, what would be gained versus the subjectivist? He is free to reject the postulate that a god of the sort we have presented (or any god) exists, and continue on merrily with his subjectivism. The basic disagreement is in the area of first principles, and how is one to prove these? Is it not the case that all metaphysical proofs of first principles, in ethics, theology, cosmology, etc. must be circular? This is not the place for a discussion of the putative philosophical proofs of God's existence; suffice it to say that a minority of philosophers today would give them serious consideration, and even during their heyday they never obtained anything like universal acceptance. The infinite regress problem concerning ded ttive profs is well known, as is the fact that any attemr. to justify the principle of induction must be circular. Sidgwick has pointed out, and Roger Hancock agrees that fundamental axioms of ethics ". . cannot be proved and must be regarded as known directly, without proof: there is no clear sense in which we can speak of proving or giving evidence for them, without circularity." 80 This appears to leave us with recourse 
only to some sort of insight regarding first principles. However, since insights are, by definition, foundational, there can be no appeal to any criteria for adjudicating between competing claims which are presented as "insights," in ethics or anywhere else. The best that can be done in a dispute is to present examples and attempt to elicit agreement on general principles on the basis of them. This is essentially what veatch does when he gives illustrations such as that of Socrates' conduct under the Thirty. Veatch says, in effect, "here is an instance of a true serse of justice; surely you see it as such."

Where does all of this leave us with regard to the establishment of claims for first principles in ethics? Not very well off, I'm afraid. To the naturalist who asks, "why should I believe in the theist's God?" the answer can always be given, "why should I believe that the satisfaction of desires is good?" To the linguistic conventionalist who poses the same question, the retort can always be made, "why should I believe that I have an obligation to conform to the rules of an institution just because I have uttered words which verbally commit me to do so?" Such examples could be multiplied. The proposition that there is such a thing as "the moral point of view," one according to which the claims of one individual to some right or good are as worthy of respect as similar claims made by anyone else, is an example of an unprovable ethical axiom. To use Fishkin's 
terminology neither "internal strategies" for justifying a particular moral position, that is, those "based on assumptions internal to the characterization of morality or the moral point of view" 81 [and therefore acknowledging that there is some "moral point of view" to be characterized appropriatelyl, nor "external strategies," that is, those which are "based on assumptions independent of the characterization of morality or the moral point of view itself-assumptions, for example, about God, meta-physics, or the role of humanity in the universe, 82 can successfully justify an ethical position so that it is secure from subjectivist attack. The latter may always reject any particular characterization of the moral point of view or any particular fundamental assumption upon which an external strategy of justification is based. As these normally involve fundamental or axiomatic assumptions, we are brought face to face with the basic epistemological problem.

If we agree with Sidgwick, Mill, Mary Warnock, and others that questions of ultimate ends, about what is ultimately desirable, are not susceptible to proof, where can we go from there? Herbert Feigl, acknowledging the limits of logical demonstration, is "inclined to say that you won't get any place with ethical justification unless you start with certain commitments" 83 which can be neither proved nor disproved. He defines commitment as the taking of a firm attitude toward something, noting that it "is itself not a 
knowledge claim at al1."84 In another passage Feigl elaborates:

". . ethical imperatives must be based upon a fundamental or supreme ethical imperative that is unconditional; that is, if your intuitions are correct, because somewhere in the analysis of moral behavior and toral experience we do come upon certain terminal values. We are not talking about absolute values, but some that furnish the basis to the rest of our values. And these are the ones to which we commit ourselves, at least as principles of criticism, even if we do not always obey them." 85

Feigl's "commitments" are not knowledge claims, yet they are fundamental ethical imperatives, non-cognitive starting points or first principles. Their resemblance to the freely chosen values of the existentialist is startling. From his explanation it clearly makes no sense to ask for the reasons for ethical commitments. If there were any to be given, then the commitments would rest upon something logically prior and no longer be first principles. We might perhaps inquire after the causes of a given individual's making of a certain commitment. Pursuing this line, however, would result in epistemology trailing off into psychology.

Despite the above difficulties with Feigl's notion of commitment, I believe that he has touched upon something valuable and important which may yet point toward a way of avoiding complete epistemological skepticism. When he talks about correct ethical intuitions and terminal values, what he says strikes a responsive chord. This is because most of us do in fact share certain fundamental ethical notions. 
Speaking on an informal, common sense level it may be claimed that all but the most depraved individuals hold certain moral principles in common (e.g., that willful, unprovoked murder is wrong). As a formal argument this approach is obviously question-begging in its use of "cepraved." Nevertheless, this to some extent common moral consciousness may be seen as evidence that genuine insights into ethical norms governing human behavior are possible. Such insights must be based on some notion of morally relevant value, that is a value such that the response to it may be the bearer of moral predicates such as right and wrong. Stones are not seen as possessing such a value; people are.

If, for the sake of discussion we grant the existence of morally relevant value and the validity of insights based thereon, we may ask what the necessary conditions for the existence of these phenomena are. That is, we may approach the matter in terms of what may loosely be described as a transcendental justification. Along this line I would ask the following question: can morally relevant value and insights pertaining to what constitutes ethical behavior have an ontological basis in an impersonal absolute or absolutes (e.g., Platonic forms)? I have already argued at some length that they cannot be found in impersonal nature (the failure of attempts to derive an "ought" from an "is"). Is the chance substantially better where some sort of impersonal absolute is brought into the picture? Remember, we 
are dealing with ethical injunctions concerning personal conduct and a unique sort of value pertaining predominately if not exclusively to people. Must not such a value and ethical norms based on it have its source in a person? If this value and the insights based thereon are objective and universally binding, must the personal source not be one akin to the Judaeo-Christian notion of God? Such would appear to be the case to this writer.

In the introauction I asked if my definition of "objective" was such that ethical norms of this sort could only emanate from God? If so a positive statement of my thesis would appear to involve a petitio principii. I would be asking whether "objective" norms, ciefined in a way that implied that they were divinely issued commands, were possible without a divine source. The answer would be, trivially, "no." Admittedly I have operated with a definition of "objective" which is somewhat loose. Nevertheless, I do not believe that it is a question begging one. The authors whose theories we ave examined have, with the probable exception of searle, attempted to develop and/or show the possibility of norms which could be described as objective in my sense of the term without bringing God into the picture. Furthermore, it remains possible, in theory, to find an impersonal transcendent source of such objective norms, though I have attempted to discredit such a move with my "transcendental" argument. I claim no certainty for its 
success; indeed I have claimed no certainty for the cardinal point of this thesis. In view of the obvious strain of epistemological skepticism which has been evident throughout this closing section, it is clear that I am not prepared to defend any claims of certainty where purported propositional truths are concerned. This final remark may point toward another, experiential notion of truth, one which cannot be captured in propositional terms, but we cannot go into that here. 
FOOTNOTES

1. L'Existentialisme est un humanisme (Existentialism), Translated by Bernard Frechtman (New York: Philosophical Library, 1947), p. 26.

2. Good and Evil (London: Collier-Macmillan, 1970), p. xi.

3. Ibid.

4. Ethics Since 1900 (Oxford, London, New York: Oxford University Press, 1978), p. 136.

5. Ibid., p. 143.

6. Beyond Subjective Morality (New Haven and London: Yale University Press, 1984), p. 12 .

7. Ibid., p. 7 .

8. "The New Barbarians of Virtue," Free Inguiry, Vol. 5, No. I (Winter $1984 / 85$ ), p. 4 .

9. "Humanistic Ethics and the Conflict of Interests," Moral Problems in Contemporary Society, Edited by Paul Kurtz (Englewood Cliffs, NJ: Prentice-Hall Inc., 1969), p. 265.

10. Good and Evil, p. 14 .

11. Ibid., p. 134 .

12. Ibid., p. 136.

13. Ibid., p. 187.

14. Ibid., p. 105.

15. Ibid., p. 34 .

16. Ibid., p. 197.

17. Ibid.

18. Ibid., p. 132.

19. Ibid., p. 130.

20. Ibid., p. 138. 
21. Ibid.

22. Ibid., p. 142 .

23. Ibid., p. 143 .

24. Ibid.

25. The Methods of Ethics (Chicago: The University of Chicago Press, 1962), p. 404.

26. A Theory of Justice (Cambridge, MA: Belknap Press of Harvard University Press, 1971), p. I36.

27. Beyond Subjective Morality, p. 91.

28. Ibid., p. 94 .

29. Good and Evil, p. 214 .

30. Ibid.

31. Ibid., p. 221 .

32. Ethics and Language (New Haven: Yale University Press, 1944), p. 113 .

33. For An Ontology of Morals (Evanston, IL: Northwestern University Press, 1971), p. 43.

34. Speech Acts (Cambridge: Cambridge University Press, 1969), p. I87.

35. Ibid., p. 133.

36. Ibid.

37. Ibid., p. 180.

38. Ibid., p. 178.

39. Ibid., p. 179.

40. Ibid.

41. Ibid., p. 180.

42. Ibid.

43. Ibid., p. 181. 
44. Ibid., p. 184.

45. Ibid., p. 51 .

46. Ibid., p. 35.

47. Ibia., p. 185.

48. Ibid., p. 186.

49. Ibid., p. 190.

50. Ibid., p. 194.

51. Ibid., p. 189.

52. For An Ontology of Morals, p. 45.

53. I'Existentialisme est un humanisme, p. 54.

54. Being and Nothingness, Translated by Hazel E. Barnes (New York: Philosophical Library, 1956), p. 543.

55. An Existentialist Ethics (New York: Vintage Books, 1967), p. $\frac{\text { s. }}{53}$

56. Ibid., p. 61 .

57. Ibid.

58. For An Ontology of Morals, p. 81 .

59. Ibid.

60. Ibid., p. 76.

61. Ibid., p. ix.

62. Ibid., p. 140.

63. Ibid., p. 106.

64. Ibid., p. 16.

65. Ibid., p. 104.

66. Ibid., p. 105.

67. Ibid., p. 107.

68. Ibid., p. 108. 
69. Ibid., p. 109.

70. Ibid., p. 112 .

71. Ibid.

?2. Ibid., p. 113.

73. Ibid., p. 115.

74. Ibid., p. 123.

75. Ibid., p. 137.

76. Ibid., p. 123.

77. Ibid., P. 118.

78. Ibid., F. 123.

79. Ibid.

80. Twentietr Century Ethics (New York and London: Columbia University Press, 1974), p. 226.

81. Beyond Subjective Morality, p. 153.

82. Ibid.

83. "Ethics, Religion, and Scientific Humanism," Moral Problems in Contemporary Society, p. 58 .

84. Ibid., p. 54 .

85. Ibid., p. 59. 


\section{BIBLIOGRAPHY}

Ayer, Alfred Jules. Language, Truth, and Logic. London: Victor Gadlancz Ltd. 1948.

Baier, Annette C. "Some Thoughts on How We Moral Philosophers Live Now." The Monist, Vol. 67, No. 4 (Oct. 1984).

Baier, Kurt. "Meaning and Morals." Moral Problems in Contemporary Society. Edited by Paul Kurtz. Englewood Cliffs, NJ: Prentice-Hall Inc. 1969.

Barnes, Hazel E. An Existentialist Ethics. New York: Vintage Books. 1967.

BJanshard, Bräd. Reason and Goodness. London: George Allen \& Unwin Ltd. and New York: The Macmillan Co. 1961.

Clark, Gordon. A Christian View of Men and Things. Grand Rapids, MI: Baker Book House. 1981.

Edwards, Paul. The Logic of Moral Discourse. Glencoe, IL: Free Press. 1955.

Farber, Marvin. "Humanistic Ethics and the Conflict of Interests." Moral Problems in Contemporary Society.

Feigl, Herbert. "Ethics, Religion, and Scientific Humanism." Mora]. Problems in Contemporary Society.

Fishkin, James. Beyond Subjective Morality. New Haven and London: Yale University Press. 1984.

Flynn, Thomas R. Sartre and Marxist Existentialism. Chicago and London: The University of Chicago Press. 1984 .

Hancock, Roger. Twentieth Century Ethics. New York and London: Columbia University Press. 1974.

Handy, Rollo. "Ethical Theory, Human Needs, and Individual Responsibility." Moral Problems in Contemporary Society.

Hare, R.M. The Language of Morals. Oxford: Clarendon Press. 1952 .

Kary, Carla E. "Sociobiology and Normative Fthics." The Monist, Vol. 67, No. 2 (April, 1984). 
Kurtz, Paul. "The New Barbarians of Virtue." Free Inquiry, Vol. 5, No. 1 (Winter 1984/85).

McCullagh, C. Behan. "The Intelligibility of Cognitive Relativism." The Monist, Vol. 67, No. 3 (July, 1984).

Nielson, Kai. "Ethics Without Religion." Moral Problems in Contemporary Society.

Rawls, John. A Theory of Justice. Cambriäge, MA: Belknap Press of Harvard University Press. 1971.

Sartre, Jear-Paul. Being and lothingness. Translated by Hazel E. Barnes. New York: Philosophical Iibrary. 1956 .

- L'Existertialisme est un humanisme (Existentialism). Translated by Bernard Frechtman. New York: Philosophical Library. 1947.

Searle, John R. Speech Acts. Cambridge: Cambridge University Press. 1969.

Sidgwick, Henry. The Methods of Ethics. Chicago: The university of Chicago Press. 1962 .

Stevensor, C.I. Ethics and Language. New Haven: Yale University Press. 1944.

Taylor, Richard. Good and Evil. Iondon: Collier-Macmillan Ltd. 1970.

Veatch, Henry. For An Ontology of Morals. Evanston, IL: Northwestern University Press. 1971.

Warnock, G.J. The object of Morality. London: Methuen \& Co. Ltd. 1971 .

Wärnock, Mary. Ethics Since 1900. Oxford, London, New York: Oxford University Press. 1978.

- Existentialism. London, Oxford, New York: Oxford University Press. 1970.

- The Philosophy of Sartre. London: Hutchinson \& Co. Lta. 1965.

Wolff, Robert Paul. Understanding Rarils: A Reconstruction and Critique of Jdin Rawls's A Theory of Justice.

Princeton: Princeton University Press. 1977.

Young, william. Foundations of Theory. Nutley, NJ: Craig Press. $196 \overline{7 .}$ 